\title{
EFEKTIVITAS MODEL BLENDED LEARNING DALAM MENINGKATKAN HAFALAN HADITS PESERTA DIDIK DI SDIT MUTIARA CENDEKIA LUBUKLINGGAU
}

\author{
1Peni Nur Syamsiah, ${ }^{2}$ Muhammad Yusuf \\ 1UIN Sunan Kalijaga Yogyakarta, ${ }^{2}$ UIN Sunan Kalijaga Yogyakarta \\ ${ }^{1}$ peninurs96@gmail.com, ${ }^{2 m o e h a m m a d y u s u f 45 @ g m a i l . c o m ~}$
}

\section{ABSTRACT}

Hadith memorization is one aspect that needs to be improved. However, during the Covid-19 pandemic, the quality of students' memorization of hadith experienced a decline. The blended learning model is the learning alternative chosen by SDIT Mutiara Cendekia Lubuklinggau. The blended learning model is a combination of face-to-face and online learning models. This study used a paired sample T-test. The mean value of the pre-test and post-test between the experimental and control groups was 40.48 with a standard deviation of 10.607. The significance value received is 0.000 , it is said that Ha is accepted and Ho is rejected, which means that there is a significant difference between the two.

\section{ABSTRAK}

Hafalan hadits merupakan salah satu aspek yang perlu diperhatikan peningkatakannya. Namun, pada masa pandemi Covid-19 kualitas hafalan hadits peserta didik mengalami penurunan. Model blended learning menjadi alternatif pembelajaran yang dipilih oleh SDIT Mutiara Cendekia Lubuklinggau. Model blended learning ialah penggabungan model pembelajaran secara tatap muka dan online. Penelitian ini menggunakan Uji paired sample T-test nilai Mean pada pre-test dan post-test antara kelompok Eksperimen dan kontrol yaitu 40,48 dengan standar deviasi sebesar 10,607. Nilai signifikansi yang diterima 0,000, maka dikatakan Ha diterima dan Ho ditolak yang berarti terdapat perbedaan yang signifikan diantara keduanya.

\section{ARTICLE HISTORY}

Received 05 Juli 2021

Revised 15 September 2021

Accepted 24 September 2021

\section{KEYWORDS}

Blended Learning, Hafalan hadits, Peserta Didik 
RABBANI

\section{PENDAHULUAN}

Sejak kehadirannya pada akhir Desember 2019 lalu, virus yang WHO beri nama Severe acute respiratory syndrome coronavirus-2 (SARSCoV-2) atau paling banyak dikenal dengan Covid-19 telah meresahkan masyarakat global, tak terkecuali di negara Indonesia. Kementrian Kesehatan melaporkan bahwa total kasus konfirmasi Covid-19 global per tanggal 11 februari 2021 adalah 106.991 .090 kasus, dengan 2.347.015 kematian (CFR 2,2\%) di 222 negara terjangkit dan 184 negara transmisi lokal. ${ }^{1}$ Hal tersebut berdampak pada hampir setiap sektor kehidupan manusia baik ekonomi, agama, psikologi dan tak terkecuali pada bidang pendidikan. Mendikbud kemudian pada tanggal 24 Maret 2020 menerbitkan Surat Edaran Nomor 4 Tahun 2020 yang menyatakan bahwa untuk setiap Satuan Pendidikan selama Masa Darurat Covid-19 agar pelaksanaan kegiatan pembelajaran dilakukan dari rumah secara daring (online) dalam rangka mencegah penyebaran Covid-19.2 Peralihan kondisi ini membuat lembaga satuan pendidikan memikirkan strategi dan metode yang tepat agar proses pembelajaran secara daring ini bisa berjalan dengan baik serta tujuan pembelajaran bisa tercapai sesuai yang diharapkan. Salah satunya adalah pengupayaan dalam meningkatkan hafalan hadits peserta didik sebagai salah satu aspek keberhasilan dalam mata pelajaran Al-Qur'an Hadits.

Hadits merupakan salah satu materi yang wajib dikuasai oleh para peserta didik yang menempuh pendidikan di sekolah-sekolah Islam. Kedudukannya yang menempati posisi kedua sebagai sumber hukum utama dalam agama Islam setelah Al-Qur'an menjadikan hadits penting untuk dipelajari terlebih lagi dihafal oleh setiap generasi Muslim. Hadits menurut bahasa artinya baru, sesuatu yang dibicarakan dan dinukil, juga berarti sesuatu

\footnotetext{
${ }^{1}$ Kemenkes, "Situasi Terkini Perkembangan Corona virus Disease." Diakses 25 Juni 2021, dari https://covid19.kemkes.go.id/situasi-infeksiemerging/situasi-terkini perkembangan corona virus-disease-covid-19-14-februari-2021.

2 Kemendikbud, "Surat Edaran Nomor 4 Tahun 2020 tentang Pelaksanaan Kebijakan Pendidikan dalam Masa Darurat Penyebaran Coronavirus Disease (COVID-19)." Diakses 25 Juni 2021, dari https:// pusdiklat.kemdikbud.go.id/surat-edaran-mendikbud-no-4-tahuntentang pelaksanaankebijakan-pendidikan-dalam-masa-darurat-penyebaran-corona-virus-disease-covid-1-9/.
} 
yang sedikit dan banyak. Sedangkan secara istilah, Hadits menurut ahli hadits ialah apa yang disandarkan kepada Nabi Muhammad SAW, baik berupa ucapan, perbuatan, penetapan, sifat atau sirah beliau, baik sebelum diangkat menjadi Nabi ataupun sesudahnya. ${ }^{3}$

Dalam mengajarkan hafalan hadits kepada peserta didik, terutama pada tingkat Sekolah Dasar yang notabene merupakan siswa yang masih tergolong anak usia dini, maka seorang guru memerlukan upaya-upaya yang tidak hanya memperhatikan satu aspek tertentu, namun dibutuhkan usaha secara komprehensif. Karena setiap anak memiliki ciri perkembangannya masingmasing, sehingga dibutuhkan cara yang berbeda-beda pula dalam menyikapi setiap peserta didik. Seorang guru perlu menerapkan strategi, metode bahkan pendekatan yang tepat sesuai tingkat kemampuan siswa agar tujuan-tujuan pembelajaran bisa tercapai.

Dalam Islam sebenarnya cukup banyak ditemukan dalil dari Al-Qur'an maupun hadits Nabi yang mengindikasikan kepada penyesuaian terhadapa kondisi ataupun tingkat kemampuan peserta didik dalam menyampaikan materi atau penggunaan metode dalam pembelajaran. Penulis akan menjabarkan satu hadits yang menggambarkan hal tersebut, yaitu hadits dari Anas bin Malik ra yang diriwayatkan oleh Imam Bukhori: ${ }^{4}$

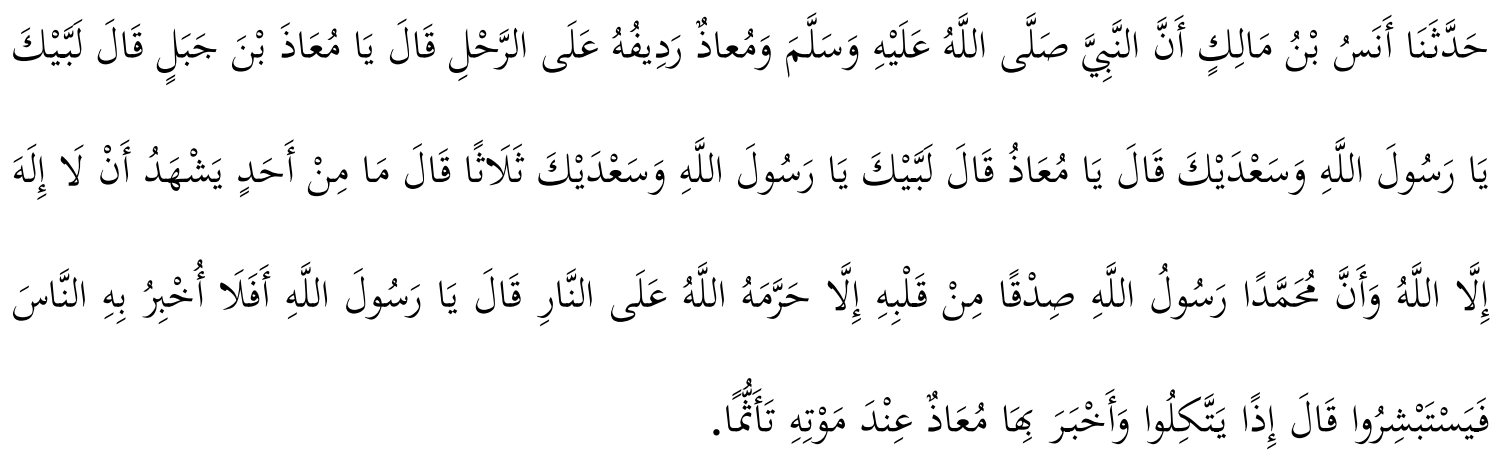

\footnotetext{
${ }^{3}$ Syekh Manna Al-Qaththan, Pengantar Studi Ilmu Hadits (Jakarta: Pustaka Al-Kautsar, 2015), hlm. 22.

${ }^{4}$ Aat Hidayat, "Ayat Al-Qur'an dan Hadis Nabi tentang Prinsip Penyampaian Pelajaran Sesuai Kemampuan Siswa," Jurnal Penelitian vol. 10, no. 1 (Februari 2016), hlm. 187.
} 
Dari Anas bin Malik, dia berkata: Nabi saw. pernah membonceng Mu'adz bin Jabal. Rasulullah saw. pada saat itu memanggil Mu'adz, "Wahai Mu'adz bin Jabal!" Mu'adz kemudian menjawab, "Aku sambut seruanmu wahai Rasulullah dan aku taati perintahmu." Rasulullah saw. memanggil Mu'adz lagi, "Wahai Mu'adz!" Mu'adz menjawab, "Aku sambut seruanmu wahai Rasulullahdan aku taati perintahmu." Rasulullah saw. mengulangi panggilannya hingga tiga kali. Kemudian Rasulullah saw. bersabda, "Tidak seorang hambapun yang bersaksi secara sungguh-sungguh dari lubuk hatinya bahwa tiada tuhan selain Allah dan Muhammad adalah hamba dan rasul-Nya, melainkan Allah akan mengharamkan hamba tersebut masuk neraka." Mu'adz bertanya, "Wahai Rasulullah saw., apakah hal ini dapat aku informasikan kepada manusia agar mereka senang?" Rasulullah saw. menjawab, "Jangan, sebab mereka akan enggan untuk beramal." Namun, menjelang ajalnya menginformasikan hal tersebut. Hal itu dia lakukan karena takut akan memperolah dosa karena menyembunyikan ilmu.

Dalam hadits di atas digambarkan secara tersirat tentang penahapan peserta didik dalam mempelajari suatu ilmu pengetahuan melalui contoh dari Rasulullah saw kepada sahabatnya, yakni Mu'adz bin Jabal ra. Di kisahkan

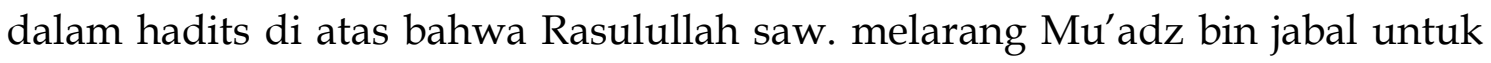
menyampaikan kepada orang lain tentang keutamaan mengucapkan dua kalimat syahadat. Alasannya adalah agar orang yang mendengar informasi tersebut tidak malas beribadah. Sebab mereka akan berpikir bahwa, kenapa harus susah payah beribadah jika dengan mengucapkan dua kalimat syahadat sudah cukup membuat seseorang masuk kedalam surga. Karena itulah Rasul melarang $\mathrm{Mu}^{\prime} \mathrm{adz}$ untuk menyampaikan perihal tersebut kepada orang lain. Selanjutnya, yang menjadi pertanyaan adalah, kenapa Rasul memilih

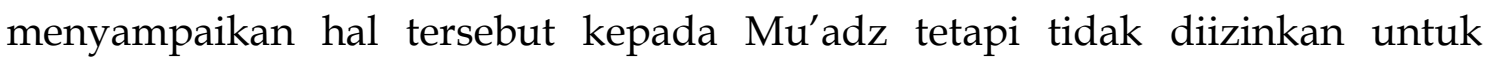
disampaikan kepada orang lain? Jawabannya adalah sebab Rasul melihat bahwa Mu'adz termasuk salah seorang sahabat yang rajin dan teguh beribadah. Rasul menganggap bahwa tidak mungkin Mu'adz akan malas mengerjakan ibadah setelah mendengar informasi tersebut. 
Selain berdasarkan hadits di atas, Hidayat juga menemukan 4 pernyataan dalam dua hadits dan dua asar yang mengindikasikan agar penyampaian dalam pembelajaran disesuaikan dengan kondisi atau kemampuan siswa, yaitu:

a. Perkataan 'Ali, “Berbicaralah kepada manusia sesuai kadar pemahaman mereka, apakah kalian rela jika Allah dan rasul-Nya didustakan?"

b. Perkataan Abdullah bin Mas'ud, “Tidaklah kamu mengatakan sesuatu kepada tidak dimengerti oleh sekelompak orang, melainkan perkataan itu bisa menimbulkan fitnah pada sebagian orang dari mereka."

c. Sabda Rasulullah, "Posisikanlah manusia sesuai kedudukan mereka."

d. Sabda Rasulullah, "Tidaklah Allah mengutus seorang nabi kecuali menggunakan bahasa yang bisa dimengerti oleh kaumnya." 5

Beberapa hadits rasul dan perkataan (asar) sahabat di atas menandakan pentingnya seorang guru dalam menyesuaikan penggunaan metode ataupun model tertentu dalam kegiatan belajar mengajar. Namun, sejak penetapan pembelajaran daring dari rumah oleh Mendikbud, ruang gerak guru dalam membantu pencapaian tujuan pembelajaran, tak terkecuali pencapaian target hafalan hadits peserta didiknya menjadi sangat terbatas. Seorang guru selama pembelajaran daring hanya mampu mengoptimalkan perannya sebagai motivator dan fasilitator, sedangkan peran lainnya beralih kepada orang tua masing-masing peserta didik. Sehingga, meskipun kegiatan belajar dari rumah ini memiliki efek positif, yaitu menghambat penyebaran Covid-19, namun pada sektor pendidikan diantaranya pencapaian hafalan peserta didik memiliki dampak yang kurang baik bagi sebagian peserta didik.

Setiap lembaga pendidikan berbeda-beda dalam menyikapi persoalan di atas mengingat kompleksnya permasalahan tersebut, karena kebijakan yang diambil akan sangat menentukan hasil yang akan dicapai. Oleh karena itu setiap kebijakan yang akan diterapkan harus mempertimbangkan berbagai aspek terutama tujuan yang akan dicapai. Selain itu, yang tidak kalah penting adalah

\footnotetext{
${ }^{5}$ Ibid., hlm. 192.
} 
pertimbangan dari aspek siswa dan guru, sampai pertimbangan materi serta sarana dan prasarana. Salah satu langkah atau kebijakan yang diambil oleh sebagian lembaga pendidikan di Indonesia adalah dengan menerapkan kebijakan blended learning, seperti kebijakan yang diterapkan oleh salah satu lembaga pendidikan di kota Lubuklinggau, yaitu SDIT Mutiara Cendekia Lubuklinggau. Kebijakan ini diambil karena selama pandemi Covid-19 kegiatan belajar mengajar hanya memanfaatkan peran teknologi, sedangkan guru hanya menjadi fasilitator dan motivator. Mereka kehilangan sebagian besar perannya sebagai seorang pendidik. Model blended learning ini dinilai sebagai pilihan yang tepat dalam kondisi seperti sekarang ini, yang tidak memungkinkan kegiatan belajar mengajar dilaksanakan secara penuh di sekolah.

Blended learning berasal dari kata blend yang artinya campuran dan learning yang artinya belajar. Blended learning merupakan penggabungan model pembelajaran secara tatap muka di ruangan kelas dengan pembelajaran secara daring. ${ }^{6}$ Pada model blended learning, pembelajaran yang biasanya dilakukan di kelas atau sering disebut dengan pembelajaran konvensional dikombinasikan dengan pembelajaran secara daring (online), secara independen ataupun kolaborasi. ${ }^{7}$ Blended learning tergolong baru dalam isu pendidikan, terlebih ditengah pesatnya perkembangan teknologi dan globalisasi. Bahkan pengertian blended learning juga telah banyak dikembangkan. Para praktisi pendidikan berbeda-beda mendefinisikan blended learning berdasarkan praktiknya.

Driscoll memberikan definisi blended learning berdasar pada 4 konsep berbeda, yaitu: pertama, merupakan pembelajaran dengan mengkombinasikan berbagai teknologi yang berbasis web, guna mewujudkan tujuan pendidikan. Kedua, mengkombinasikan berbagai pendekatan dalam pembelajaran (kognitivisme, konstruksivisme dan behaviorisme) dalam mengoptimalkan pencapaian hasil pembelajaran dengan ataupun tanpa menggunakan teknologi.

\footnotetext{
${ }^{6}$ Nurlian Nasution, dkk, Buku Model Blended Learning (Riau: Unilak Press, 2019), hlm. 30.

${ }^{7}$ Kadek Cahya Dewi, dkk, Blended Learning: Konsep dan Implementasi pada Pendidikan Tinggi Vokasi (Bali: Swasta Nulus, 2019), hlm. 15.
} 
Ketiga, blended learning juga mengkombinasikan banyak dari format teknologi pembelajaran (seperti CD-ROM, video tape, Web Based Training, film) dengan pembelajaran tatap muka. Keempat, blended learning merupakan gabungan teknologi pembelajaran dengan perintah tugas dalam pekerjaan untuk menghasilkan sinergi positif dalam pembelajaran dan pekerjaan. ${ }^{8}$

Dari keempat pengertian yang dikemukakan Driscoll di atas, dapat disimpulkan bahwa pada perkembangannya blended learning tidak lagi dimaknai sekedar kombinasi antara pembelajaran secara online dan face to face, akan tetapi dengan menggabungkan beberapa pendekatan dalam kegiatan pembelajaran, meskipun tanpa menggunakan produk teknologi sudah dapat dikategorikan sebagai pembelajaran blended learning.

Menurut Oliver, setelah melakukan survey menyimpulkan ada beberapa aspek dalam model blended learning, yaitu: Mode delivery, yaitu kombinasi conventional learning dengan pendekatan berbasis web online; Teknologi, yaitu penerapan kombinasi penggunaan media dan teknologi; Pedagogi, yaitu gabungan beberapa pendekatan pedagogi; dan Kronologi, yaitu pendekatan synchronus dan asynchronus. ${ }^{9}$ Selain aspek-aspek blended learning di atas, Winarno mengembangkan tiga karakteristik dari pembelajaran model blended learning, yaitu: Pertama, pembelajaran model blended learning menggabungkan berbagai cara dalam menyampaikan materi ajar, mulai dari model, gaya sampai teknologi atau media tertentu pada proses pembelajarannya. Jika dimanfaatkan sebaik mungkin maka hasil dari proses pembelajaran ini juga akan maksimal. Kedua, pembelajaran ini berbasis media serta teknologi khususnya teknologi informasi, namun tetap bisa digabungkan dengan model pembelajaran konvensional. Ketiga, pengajar dalam hal ini guru sewaktu-waktu hanya berfungsi sebagai

\footnotetext{
${ }^{8}$ Nurlian Nasution, dkk, Buku Model Blended Learning..., hlm. 32.

9 Kadek Cahya Dewi, dkk, Blended Learning: Konsep dan Implementasi pada Pendidikan Tinggi Vokasi..., hlm. 17.
} 
fasilitator yang menunjang peserta didik untu mandiri dalam belajar dan mengembangkan materi yang telah mereka dapatkan. ${ }^{10}$

Berdasarkan beberapa aspek dan karakteristik di atas, bisa dilihat bahwa model blended learning menuntut adanya sinergitas antara kemampunan pengajar (memilih strategi, media yang tepat dalam mengajar dan memilih materi ajaran) dengan keinginan serta kemandirian siswa dalam belajar dan mengembangkan materi yang telah diajarkan. Selain itu pengetahuan dalam menggunakan produk teknologi yang digunakan, baik dari sisi siswa terlebih guru sebagai fasilitator, sangat ditekankan dalam menunjang dan memaksimalkan hasil pencapaian pembelajaran dengan model blended learning.

Selain faktor guru dan siswa, dari sisi lembaga pendidikan juga sangat mempengaruhi keberhasilan penerapan blended learning, seperti alokasi layanan yang disediakan dalam mendukung dan membantu siswa maupun guru yang berkaitan dengan penggunaan dan pengembangan modul. Kemudian termasuk juga pengeluaran untuk tambahan sumber daya di bidang komunikasi yang memungkinkan dan mendorong guru menjadi semakin aktif terlibat dan sepenuhnya sadar akan kegunaan blended learning.

Sinergitas antar berbagai elemen pendidikan di atas (guru, peserta didik maupun lembaga pendidikan) juga sangat dibutuhkan jika ingin memaksimalkan pengajaran materi hafalan pada peserta didik. Dimana guru selain menyediakan materi yang akan dihafalkan oleh para peserta didik, juga perlu menerapkan strategi dan pendekatan tertentu yang dapat memudahkan dan menumbuhkan semangat peserta didik dalam menghafal. Kemudian aspek kedua adalah motivasi dan kemandirian peserta didik sendiri untuk menambah hafalannya. Seperti yang dikemukakan oleh Hidayah bahwa diantara penyebab kegagalan dalam mengajarkan hafalan kepada peserta didik, diantaranya karena manajemen dari lembaga sendiri yang cukup lemah, karena faktor pengajarnya, yaitu guru kurang aktif membimbing dan memotivasi peserta didik, mekanisme

10 Ari Tri Winarno, Blended Learning and Cyber Non-Formal Education (Surabaya: Garuda Mas Sejahtera, 2018), hlm. 57-58. 
dan metode yang kurang tepat, kemudian yang terakhir dia juga menambahkan bahwa faktor dukungan dari orang tua juga perlu ditingkatkan. ${ }^{11}$

\section{METODE PENELITIAN}

Berdasarkan latar belakang masalah di atas, metode penelitian yang penulis gunakan adalah penelitian kuantitatif dan jenis penelitian eksperimen semu (quasi eksperimen) serta, menggunakan desain pre-test-post-test non equivalent control group design. ${ }^{12}$ Metode quasi eksperimen merupakan bentuk penelitian dengan ciri-ciri validitasnya dilakukan tidak dengan acak, melainkan memilih kelas atau kelompok yang ada.

Penelitian ini dilakukan dengan memberikan treatment kepada kelompok eksperimen yaitu diterapkan metode blended learning dan menyediakan kelompok kontrol sebagai pembanding. Dalam rancangan penelitian ini observasi dilakukan sebanyak 2 kali yaitu sebelum eksperimen dengan diberikan pretest dan sesudah eksperimen dengan diberikan posttest. 13

\begin{tabular}{ccc}
\hline Pre-test & $\begin{array}{c}\text { Independent } \\
\text { /Treatment }\end{array}$ & Post-test \\
\hline $\mathrm{O}_{1}$ & $\mathrm{X}$ & $\mathrm{O}_{2}$ \\
\hline $\mathrm{O}_{3}$ & - & $\mathrm{O}_{4}$ \\
\hline
\end{tabular}

\section{Gambar 1: Desain Penelitian Pre-test dan Post-test}

Keterangan:

$\mathrm{O}_{1}$ : kemampuan pada kelompok eksperimen (sebelum diberi perlakuan)

$\mathrm{O}_{2}$ : kemampuan pada kelompok eksperimen (sesudah diberi perlakuan)

$\mathrm{O}_{3}$ : kemampuan pada kelompok kontrol (sebelum diberi perlakuan)

$\mathrm{O}_{4}$ : kemapuan pada kelompok kontrol (sesudah diberi perlakuan)

$\mathrm{X}$ : Treatment menggunakan model Blended Learning

Populasi adalah wilayah generalisasi yang terdiri atas subjek atau objek yang mempunyai kualitas dan karakteristik tertentu yang ditetapkan oleh

\footnotetext{
${ }^{11}$ Nurul Hidayah, “Strategi Pembelajaran Tahfidz Al-Qur'an di Lembaga Pendidikan,” Ta'allum: Jurnal Pendidikan Islam vol. 4, no. 1 (2016), hlm. 69-70.

${ }^{12}$ Sugiyono, Metode Penelitian kuantitatif (Bandung: Alfabeta.Sugiyono, 2018), hlm. 79.

${ }^{13}$ Emzir, Metodologi Penelitian Pendidikan (Jakarta: Rajawali Pers, 2012), hlm. 64.
} 
peneliti untuk dipelajari dan ditarik kesimpulannya. ${ }^{14}$ Populasi dalam penelitian ini fokus pada peserta didik kelas III SDIT Mutiara Cendekia Lubuklinggau yang berjumlah sebanyak 55 orang. Jika semua populasi diambil secara menyeluruh, maka akan membutuhkan waktu dan dana yang tidak sedikit. Solusi untuk dapat mewakili dari data populasi secara keseluruhan, diperlukan beberapa sampel penelitian sebagai perwakilan.

Sampel penelitian merupakan unsur dari suatu jumlah serta karakteristik yang dimiliki oleh populasi. ${ }^{15}$ Sampel yang digunakan dalam penelitian ini, terdiri dari kelas $\mathrm{III}_{\mathrm{A}}$ berjumlah 25 orang dan kelas $\mathrm{III}_{\mathrm{B}}$ berjumlah 25 orang. Kelas III $_{\mathrm{A}}$ sebagai kelas eksperimen (diterapkan model blended learning) dan kelas III $_{\mathrm{B}}$ sebagai kelas kontrol (tidak diterapkan model blended learning). Teknik penelitian yang penulis gunakan dalam mengambil sampel ialah purposive sampling atau teknik pengambilan sampel sesuai pertimbangan tertentu.

Teknik analisis yang dilakukan menggunakan tiga tahap, yaitu: 1) Uji normalitas yang dilakukan agar mengetahui, sampel yang digunakan normal atau tidak. Dalam menguji normalitas peneliti menggunakan bantuan SPSS 25.0 yakni menggunakan uji Shapiro-Wilk. 2) Uji hipotesis digunakan dalam rangka mengetahui terdapat pengaruh yang signifikan antara model blended learning terhadap peingkatan hafalan hadits peserta didik di SDIT Mutiara Cendekia Lubuklinggau. 3) Uji N-Gain digunakan untuk mengukur keefektifan dari hafalan hadits peserta didik di di SDIT Mutiara Cendekia Lubuklinggau.

\section{HASIL DAN PEMBAHASAN}

1. Analisis deskriptif

Tabel 1

Descriptive Statistics

\begin{tabular}{|c|c|c|c|c|c|}
\hline \multicolumn{6}{|c|}{ Descriptive Statistics } \\
\hline & $\mathrm{N}$ & Minimum & Maximum & Mean & Std. Deviation \\
\hline Pre-Tset Eksperimen & 25 & 22 & 66 & 40,48 & 10,607 \\
\hline
\end{tabular}

\footnotetext{
14 Sugiyono, Metode Penelitian kuantitatif..., hlm. 80.

15 Sugiyono, Metode Penelitian Pendidikan (Bandung: Alfabeta, 2018), hlm. 118.
} 


\begin{tabular}{|l|r|r|r|r|r|}
\hline Post-Test Eksperimen & 25 & 73 & 98 & 86,88 & 8,358 \\
\hline Pre-Test Kontrol & 25 & 15 & 55 & 35,36 & 10,855 \\
\hline Post-Test Kontrol & 25 & 55 & 95 & 75,28 & 10,865 \\
\hline Valid N (listwise) & 25 & & & & \\
\hline
\end{tabular}

Berdasarkan Tabel 1.2 Descriptive Statistics, output SPSS menunjukkan bahwa jumlah responden $(\mathrm{N})$ ada 25, dari 25 responden nilai minimun yang diperoleh ialah 22, sedangkan nilai maksimum yang diperoleh ialah 66. Jadi, rata-rata nilai dari 25 responden atau mean sebesar 40,48 dengan standar deviasi sebesar 10, 607 .

2. Uji normalitas

Uji normalitas digunakan untuk mengetahui data penelitian yang sudah didapatkan berdistribusi normal atau tidak. Pada penelitian ini uji normalitas menggunakan SPSS 25.0 yaitu menguji Kolmogrov-Smirnov maupun ShapiroWilk. Data dinyatakan berdistribusi normal atau tidak dengan kriteria: jika signifikansi atau Sig. (2-tailed) > 0,05 maka Ho diterima, jika signifikansi atau Sig. (2-tailed) $<0,05$ maka Ho ditolak.

Tabel 2

Tests of Normality

\begin{tabular}{|l|l|r|r|r|r|r|r|}
\hline \multicolumn{9}{|c|}{ Tests of Normality } \\
\hline \multirow{3}{*}{} & \multirow{2}{*}{ Kelas } & \multicolumn{2}{|c|}{ Kolmogorov-Smirnova } & \multicolumn{3}{|c|}{ Shapiro-Wilk } \\
\cline { 2 - 8 } & Statistic & df & \multicolumn{1}{|c|}{ Sig. } & Statistic & df & \multicolumn{1}{c|}{ Sig. } \\
\hline \multirow{3}{*}{ Hasil belajar } & Pre-Test Eksperimen &, 089 & 25 &, $200^{*}$ &, 980 & 25 &, 895 \\
\cline { 2 - 8 } & Post-Test Eksperimen &, 128 & 25 &, $200^{*}$ &, 921 & 25 &, 055 \\
\cline { 2 - 9 } & Pre-Test Kontrol &, 117 & 25 &, $200^{*}$ &, 969 & 25 &, 615 \\
\cline { 2 - 9 } & Post-Test Kontrol &, 118 & 25 &, $200^{*}$ &, 966 & 25 &, 552 \\
\hline
\end{tabular}

*. This is a lower bound of the true significance.

a. Lilliefors Significance Correction

Berdasarkan hasil Tabel 1.3 Tests of Normality, menyatakan bahwa nilai signifikansi dari setiap varians memperlihatkan $>0,05$. Disimpulkan bahwa, variabel pre-test dan post-test kelompok eksperimen dan kontrol, populasi berdistribusi normal. 
RABBANI

3. Uji hipotesis

Uji hipotesis merupakan suatu ketentuan dalam memutuskan apakah hipotesis tersebut diterima atau ditolak. ${ }^{16}$ Uji hipotesis dilakukan pada SPSS 25.0 paired samples statistics dengan batas signifikansi 0.05, yang menjadi dasar dari suatu pengambilan keputusan pada uji-t ialah jika nilai Sig. (2-tailed) < 0,05, maka Ho ditolak dan Ha diterima dan sebaliknya apabila Sig. (2-tailed) > 0.05 maka Ho diterima dan Ha ditolak.

Tabel 3

Paired Samples Test

\begin{tabular}{|c|c|c|c|c|c|c|c|c|c|}
\hline \multicolumn{10}{|c|}{ Paired Samples Test } \\
\hline & & \multicolumn{5}{|c|}{ Paired Differences } & \multirow[b]{3}{*}{$\mathrm{t}$} & \multirow[b]{3}{*}{ df } & \multirow{3}{*}{$\begin{array}{l}\text { Sig. (2 } \\
\text { tailed) }\end{array}$} \\
\hline & & \multirow[b]{2}{*}{ Mean } & \multirow{2}{*}{$\begin{array}{l}\text { Std. } \\
\text { Deviat } \\
\text { ion } \\
\end{array}$} & \multirow{2}{*}{$\begin{array}{l}\text { Std. } \\
\text { Error } \\
\text { Mean } \\
\end{array}$} & \multicolumn{2}{|c|}{$\begin{array}{l}\text { 95\% Confidence } \\
\text { Interval of the } \\
\text { Difference }\end{array}$} & & & \\
\hline & & & & & Lower & Upper & & & \\
\hline $\begin{array}{l}\text { Pai } \\
\text { r } 1\end{array}$ & $\begin{array}{l}\text { Pre-Tset } \\
\text { Eksperimen - } \\
\text { Post-Test } \\
\text { Eksperimen }\end{array}$ & $-46,400$ & 11,206 & 2,241 & $-51,026$ & $-41,774$ & $\begin{array}{l}- \\
20,70 \\
2\end{array}$ & 24 & ,000 \\
\hline $\begin{array}{l}\text { Pai } \\
\text { r } 2\end{array}$ & $\begin{array}{l}\text { Pre-Test } \\
\text { Kontrol - Post- } \\
\text { Test Kontrol }\end{array}$ & $-39,920$ & 400 & ,080 & $-40,085$ & $-39,755$ & $\begin{array}{l}- \\
499,0 \\
00\end{array}$ & 24 & ,000 \\
\hline
\end{tabular}

Berdasarakan output Pair 1 diperoleh nilai Sig. (2-tailed) sebesar 0,000 $<0,05$, maka dapat disimpulkan ada perbedaan rata-rata hasil belajar siswa untuk Pre-test kelas Eksperimen dengan Post-test kelas Eksperimen. Berdasarkan output Pair 2 diperoleh nilai Sig (2-tailed) sebesar 0,000 0,05, maka dapat disimpulkan ada perbedaan rata-rata hasil belajar siswa untuk Pre-test kelas kontrol dengan Post-test kelas kontrol. Jadi, disimpulkan bahwasannay terdapat perbedaan yang signifikan terhadap pre-test dan posttest kelas eksperimen dan kontrol.

\footnotetext{
16 I Putu Ade Andre Payadnya dan I Gusti Agung Ngurah Trisna Jayantika, Panduan Penelitian Eksperimen Beserta Analisis Statistik Dengan SPSS (Yogyakarta: Deepublish, 2018), hlm. 75.
} 


\section{Uji N-Gain}

Uji N-Gain merupakan uji yang dilakukan untuk menghitung selisih antara nilai pre-test dan post-test, yaitu menunjukkan peningkatan terhadap hafalan peserta didik digunakan rumus rata-rata gain ternormalisasi. Dalam penelitian ini, uji N-Gain dilakukan menggunakan program SPSS 25.0. Kriteria dan rumus dalam menarik kesimpulan hasil, berpedoman pada: ${ }^{17}$

$$
G=\frac{\text { Skor Postes }- \text { Skor Pretes }}{\text { Nilai Maksimum }- \text { Skor Pretes }}
$$

Tabel 4

Kategori Interpretasi N-Gain

\begin{tabular}{|c|c|}
\hline Presentase & Interpretasi \\
\hline$<40$ & Tidak Efektif \\
\hline $40-55$ & Kurang Efektif \\
\hline $56-75$ & Cukup Efektif \\
\hline$>75$ & Efektif \\
\hline
\end{tabular}

Tabel 5

Hasil Perhitungan Uji N-Gain Score

\begin{tabular}{|c|c|c|c|c|}
\hline & \multicolumn{2}{|c|}{ Hasil Perhitungan Uji N-Gain Score } & \\
\hline \multirow{2}{*}{ No } & Kelas Eksperimen & \multirow{2}{*}{ No } & Kelas Kontrol \\
\cline { 2 - 2 } & N-Gain Score (\%) & & N-Gain Score (\%) \\
\hline 1 & 95,45 & 1 & 57,14 \\
\hline 2 & 94 & 2 & 66,67 \\
\hline 3 & 94,03 & 3 & 70,18 \\
\hline 4 & 82,46 & 4 & 76,92 \\
\hline 5 & 77,05 & 5 & 88,89 \\
\hline 6 & 94,67 & 6 & 74,07 \\
\hline 7 & 78,33 & 7 & 47,06 \\
\hline 8 & 70,15 & 8 & 49,38 \\
\hline 9 & 90,91 & 9 & 74,07 \\
\hline 10 & 94 & & 10 & 57,14 \\
\hline 11 & 65,08 & 11 & 58,82 \\
\hline 12 & 87,04 & 12 & 58,46 \\
\hline 13 & 77,05 & & 86,96 \\
\hline
\end{tabular}

17 Richard R. Hake, "Interactive-engagement versus traditional methods: A six-thousand-student survey of mechanics test data for introductory physics courses." American journal of Physics Vol 66 no. 1 November 1998 https://aapt.scitation.org/doi/10.1119/1.18809, hlm. 64-74. 


\begin{tabular}{|c|c|c|c|}
\hline 14 & 41,18 & 14 & 52,63 \\
\hline 15 & 94,64 & 15 & 76,92 \\
\hline 16 & 82,46 & 16 & 60,61 \\
\hline 17 & 66,67 & 17 & 62,5 \\
\hline 18 & 88,68 & 18 & 59,7 \\
\hline 19 & 81,13 & 19 & 49,38 \\
\hline 20 & 59,09 & 20 & 53,33 \\
\hline 21 & 79,49 & 21 & 58,82 \\
\hline 22 & 64,38 & 22 & 74,07 \\
\hline 23 & 59,09 & 23 & 58,82 \\
\hline 24 & 66,2 & 24 & 61,54 \\
\hline 25 & 61,97 & 25 & 54,79 \\
\hline Rata-rata & 77,8075 & Rata-rata & 63,55561 \\
\hline Minimal & 41,18 & Minimal & 47,06 \\
\hline Maksimal & 95,45 & Maksimal & 88,89 \\
\hline
\end{tabular}

Berdasarakan output SPSS di atas, hasil dari perhitungan uji N-Gen memperlihatkan nilai Mean pada kelas Eksperimen (model blended learning) ialah sebesar 77,8075 atau $78 \%$ tergolong efektif. Dengan nilai minimal NGain sebesar $41 \%$ dan maksimal 96 \%. Untuk kelas Kontrol (metode konvensional) ialah sebesar 63,55561 atau 64 \% cukup efektif, dengan nilai minimal N-Gen sebesar 47\% dan maksimal $89 \%$. Jadi disimpulkan bahwa, model blended learning tergolong efektif dalam meningkatkan hafalan hadits peserta didik di SDIT Mutiara Cendekia.

Adapun tujuan dari penelitian ini ialah untuk mengetahui terhadap efektifitas model blended learning dalam meningkatkan hafalan hadits peserta diidk kelas III di SDIT Mutiara Cendekia. Hasil analisis dari penelitiam di atas memperlihatkan bahwa dengan menggunakannya model blended learning, peserta didik lebih mudahuntuk menghafal setiap hadits-hadits yang diberikan oleh guru di sekolah.

Penggunaan model blended learning ini memberikan kontribusi positif dalam pembelajaran, karena dengan mengkombinasikan pengajaran secara langsung (face to face) dengan pengajaran berbasis online, seorang guru dapat memberi variasi dalam menyampaikan materi ajar. Selain itu penggunaan model, gaya maupun media pengajaran yang juga bervariasi merupakan 
kelebihan yang bisa dimanfaatkan dari model blended learning ini. ${ }^{18}$ Lebih dari itu, Dziuban mengatakan bahwa pembelajaran dengan konsep blended learning inimemiliki manfaat yang tidak terbatas bahkan dikenal dengan "the new normal" dalam dunia pendidikan, melihat tidak sedikitnya konsep ini diadopsi oleh institusi-institusi pendidikan karena pembelajaran dengan pendekatan blended learning dinilai menjadi lebih optimal. ${ }^{19}$

Namun seperti kebanyakan model pembelajaran lainnya, tentu saja blended learning ini memiliki kelebihan dan kekurangan. Menurut Winarno ada beberapa kelebihan dan kekurangan dari model blended learning, diantaranya:20

Kelebihan:

a. Independent learning

Peserta didik dapat dengan leluasa mengembangkan imajinansinya terkait materi belajar secara luas. Dalam artian, peserta didik diberikan kesempatan untuk mengembangkan materi belajar secara mandiri, sehingga dapat memungkinkan peserta didik memiliki pengalaman serta pembiasaan terkait materi yang diajarkan.

b. Pemanfaatan kemajuan teknologi informasi

Dengan adanya pembelajaran model blended learning ini, secara tidak langsung peserta didik diajarkan tentang cara memanfaatkan majunya teknologi informasi yang terus berkembang di era modern seperti sekarang ini. Sehingga dapat membantu peserta didik dalam mengakses dan menemukan informasi yang baik dan akurat.

c. Mengatasi permasalahan terkait jarak dan waktu

Seperti dalam keadaan pandemi sekarang ini, model blended learning sangat membantu. Ditengah-tengah ketidakmungkinan untuk melakukan suatu

\footnotetext{
18 Zahratul Qalbi dan Saparahayuningsih,“Penggunaan Blended-Problem Based Learning di Masa Covid-19 untuk Meningkatkan Kemampuan Berpikir Kritis pada Mata Kuliah Kreativitas dan Keberbakatan," Faktor: Jurnal Ilmiah Kependidikan 8, no. 1 (Maret 2021), hlm. 3.

${ }^{19}$ Della Fadhilatunisa dkk., "Pengaruh Blended Learning Terhadap Aktivitas Belajar dan Hasil Belajar Mahasiswa Akuntansi,"Jurnal Pendidikan Akuntansi Indonesia 18, no. 2 (2020), hlm. 95.

${ }^{20}$ Ari Tri Winarno, Blended Learning and Cyber Non-Formal Education...,hlm. 62-65.
} 
pembelajaran secara tatap muka di sekolah, pembelajaran berbasis online menjadi alternatif positif saat ini.

d. Proses komunikasi secara kontinu

Blended learning memungkinkan terjadinya proses belajar dalam porsi waktu yang banyak, sehingga komunikasi antara guru dan peserta didik tidak terbatas dalam ruang kelas saja. Selain itu, blended learning juga membantu siswa yang kurang berani segan untuk berkomunikasi secara verbal dengan gurunya, sehingga seiring berjalannya waktu penggunaan media ataupun teknologi dapat membantu menumbuhkan keberanian peserta didik untuk menyampaikan pendapat.

e. Ditengah maraknya isu ataupun kasus negatif yang dialami oleh para peserta didik akibat perbuatan kurang terpuji yang dilakukan oleh oknumoknum tertentu di sekolah, blended learning bisa menjadi salah satu alternatif atas permaslahan ini.

\section{Kekurangan}

Pemanfaatan media yang dibutuhkan dalam model blended learning ini begitu kompleks, sehingga terkadang proses belajar mengajar kurang maksimal apabila sarana dan prasarana yang digunakan kurang mendukung. Selanjutnya jika media pembelajaran yang digunakan beraneka ragam akan berdampak pada lembaga yang tingkat penguasaan teknologinya masih rendah.

Terlepas dari kelebihan dan kekurangan yang telah dipaparkan di atas, penulis menilai penerapan model blended learning ini cukup efektif di terapkan ditengah keadaan pandemi seperti sekarang ini. Terlebih lagi di era teknologi informasi yang semakin pesat perkembangannya. Tidak terkecuali dalam upaya meningkatkan hafalan peserta didik, model blended learning bisa menjadi alternatif positif bagi lembaga pendidikan. Dengan penerapan blended learning ini selain peserta didik bisa melatih diri untuk mandiri dalam belajar atau meningkatkan hafalan mereka, guru masih bisa mengontrol, membimbing dan memotivasi peserta didik secara langsung di kelas, sehingga diharapkan mampu meningkatkan semangat belajar dan menghafal peserta didik. 


\section{KESIMPULAN}

Berdasarkan analisis pada penelitian di atas disimpulkan bahwa uji statistik telah menjawab hipotesis yang menjadi acuan peneliti, yaitu: nilai Mean pada pretest dan post-test antara kelompok Eksperimen (diberi treatment menggunakan model blended learning) dan kelompok kontrol (tidak diberi treatment menggunakan model blended learning) yaitu 40,48 dengan standar deviasi sebesar 10,607. Nilai signifikansi yang diterima 0,000, maka dapat dikatakan Ha diterima dan Ho ditolak yang berarti terdapat perbedaan yang signifikan diantara keduanya. Dan terdapat keefektifan pada model blended learning dalam meningkatkan hafalan hadits peserta didik sebesar 77,8075 atau 78\%. Model blended learning ialah model yang memperpadukan antara pembelajaran daring dan pembelajaran langsung (face to face), sehingga dapat memberikan kemudahan pada guru saat memberikan materi ajar dan mempermudah peserta didik dalam menghafal pembelajaran hadits di SDIT Mutiara Cendekia Lubuklinggau.

\section{DAFTAR PUSTAKA}

Al-Qaththan, Syaikh Manna. Pengantar Studi Ilmu Hadits. Jakarta: Pustaka AlKautsar, 2015.

Anwar, Desi. Kamus Lengkap Bahasa Indonesia. Surabaya: Amelia, 2003.

Dewi, Kadek Cahya, dkk. Blended Learning: Konsep dan Implementasi pada Pendidikan Tinggi Vokasi. Bali: Swasta Nulus, 2019.

Emzir. Metodologi Penelitian Pendidikan. Jakarta: Rajawali Pers, 2012.

Fadhilatunisa, Della, dkk. "Pengaruh Blended Learning Terhadap Aktivitas Belajar dan Hasil Belajar Mahasiswa Akuntansi." Jurnal Pendidikan Akuntansi Indonesia 18, no. 2 (2020).

Hake, Richard R. "Interactive-engagement versus traditional methods: A sixthousand-student survey of mechanics test data for introductory physics courses." American journal of Physics Vol 66 no. 1 November 1998 https:/ / aapt.scitation.org/doi/10.1119/1.18809 (diakses 26 Juni 2021). 
Hidayah,Nurul, “Strategi Pembelajaran Tahfidz Al-Qur'an di Lembaga Pendidikan." Ta'allum: Jurnal Pendidikan Islam 4, no. 1 (2016).

Hidayat, Aat. "Ayat Al-Qur'an dan Hadits Nabi tentang Prinsip Penyampaian Pelajaran Sesuai Kemampuan Siswa."Jurnal Penelitian 10, no. 1 (Februari 2016).

Kemendikbud. 2020. Surat Edaran Nomor 4 Tahun 2020. Pelaksanaan Kebijakan Pendidikan dalam Masa Darurat Penyebaran Coronavirus Disease (COVID-19). Diakses 24 Mei 2021, dari https:/ / pusdiklat.kemdikbud.go.id/ surat-edaran-mendikbud-no-4tahun-2020-tentang-pelaksanaan-kebijakan-pendidikan-dalam-masadarurat-penyebaran-corona-virus-disease-covid-1-9/.

Kemenkes. 2021. Situasi Terkini Perkembangan Coronavirus Disease, diakses 24 Mei 2021, dari https://covid19.kemkes.go.id/situasi-infeksiemerging/ situasi-terkiniperkembangan-coronavirus-disease-covid-19-14-februari2021.

Nasution, Nurlian, dkk. Buku Model Blended Learning. Riau: Unilak Press, 2019.

Payadnya, I Putu Ade Andre dan I Gusti Agung Ngurah Trisna Jayantika. Panduan Penelitian Eksperimen Beserta Analisis Statistik Dengan SPSS. Yogyakarta: Deepublish, 2018.

Qalbi, Zahratul, dan Sri Saparahayuningsih. "Penggunaan Blended-Problem Based Learning di Masa Covid-19 untuk Meningkatkan Kemampuan Berpikir Kritis pada Mata Kuliah Kreativitas dan Keberbakatan." Faktor: Jurnal Ilmiah Kependidikan 8, no. 1 (Maret 2021).

Sugiyono. Metode Penelitian Pendidikan. Bandung: Alfabeta, 2018.

Winarno,Ari Tri.Blended Learning and Cyber Non-Formal Education. Surabaya: Garuda Mas Sejahtera, 2018.

Yuanita, Dianis Izzatul, dan Intan Lailatul Kurniawati. “Meningkatkan Kemampuan Menghafal Hadits pada Siswa dengan Terjemah." Jurnal el Bidayah 1, no. 2 (2019).

Yunus, Mahmud. Kamus Arab Indonesia. Jakarta: PT. Mahmud Yunus Wadzuhryah, 1990. 